\title{
Research, Technology Transfer and Socio-Economic Development in Nigeria: Some Lessons from the Asian Economies
}

\author{
Harry, Deinibiteim Monimah \\ Department of Public Administration \\ Rivers State College of Arts and Science, Rumuola, \\ Port Harcourt,Nigeria
}

\section{Doi:10.5901/mjss.2013.v4n8p119}

\begin{abstract}
Like most developing countries Nigeria had made various efforts at acquiring foreign technology to drive the development processes in the country. While technology transfer efforts have been very successful in the Asian economies, especially in China, South Korea, India and Malaysia, it has not been successful in Nigeria. The difference in the level of success in the technological advancement between the Asian economies and Nigeria is in the approach or method adopted by the economies. While the Asian economies adopt the cram, copy or "steal" and replicate through intensive research to achieve innovation and patent rights, Nigeria adopt the traditional method of negotiated agreement of technology transfer with owners of technologies. The result is that whereas the Asian economies are making significant progress in acquiring technologies, Nigeria suffers deprivation in the acquisition of technology. The paper argues that Nigeria cannot acquire foreign technologies through negotiated agreements; therefore, if Nigeria must acquire technologies she must tow the line of the Asian economies. Also, it asserts that Nigeria must deliberately establish high-tech research institutions and invest significantly in the development of her human capital/resources. This is what the Asian economies have done differently.
\end{abstract}

Keywords: Nigeria, Technology transfer, negotiated agreements, cram, Asian economies, research and development.

\section{Introduction}

The desirability of African countries, especially Nigeria, to acquire advanced and modern technologies to aid their development processes need not be overemphasized. Over the years, Nigeria has made efforts to increase and improve local production, particularly in the manufacturing sector, through the acquisition of foreign technologies. Prominent among them is the adoption of the import substitution industries policy in the 1970s and early 1980s. Yet, in the twenty-first century, Nigeria has not been able to improve its technological base in the different sectors of the society. It is not therefore surprising to see Nigeria grappling with providing the basic necessities of life such as water, food, electricity, roads, etc for its citizenry. As Mansfield (1975:373) has argued, one of the fundamental processes of influencing or improving the economic performance of nations and firms is technology transfer. According to Ramanathan (2009), economists have long recognized the fact that transfer of technology is at the heart of the process of economic growth (and development), and that the progress of both developed and developing countries depends very strongly on the extent and efficiency of such transfer.

In the past three decades, many Asian and Latin American countries (some of which are called the "Asian tigers" and others part of the BRICKS nations) had experienced technological break-through in the different sectors of their societies and had improved the living conditions of their citizenry. These breakthroughs were not achieved via voluntary transfer of technology from the transferors (owners) to these 
nations (buyers or transferees) neither were they accidental. Rather these advancements in technology were gotten via concerted efforts and investments in research and development in the tertiary institutions, research institutes and production factories in these countries. Hence, the rapid improvement of these nations in the global development index or placement. The main objective of this paper is to examine or x-ray the challenges of technology transfer in Nigeria over the years in different sectors of the society. The paper would argue that owners of technologies do not and will not always voluntarily and/or willingly transfer such technologies to others. Rather technologies are "stolen" (that is capture) through concerted efforts at copy and replication, and investments in research and development. Thus, to acquire modern and advanced technologies Nigeria must toe the line of the Asian economies, especially China. This view would be developed in some greater details in the course of the discussion. The rest of the paper would be developed under the following headings: the concept of technology transfer, technology transfer and socio-economic development, technology transfer: the Asian experience, Nigeria and the dilemma of technology transfer, the role of research in technology transfer, lessons from the Asian economies, and conclusion.

\section{The Concept of Technology Transfer}

Technology is defined in terms of high-level manpower in scientific, technical and engineering fields, and expenditure on research and development as a percentage of Gross Domestic Product (Ake, 1984:106). Technologies, most often, are invented or developed in one country but utilized and enjoyed in different parts of the world. The processes through which technology invented in one part of the world is utilized or enjoyed in other parts of the world is what is generally referred to as technology transfer or technology diffusion. Bozeman (2000:629) sees technology transfer as the movement of know-how, technical knowledge, or technology from one organizational setting to another. This implies that it is not merely the movement of product(s) that is technology transfer but also the knowledge of its use and application. Mittleman and Pasha $(1997 ; 19)$ present a somewhat broader view of the concept technology transfer, which states that it is the movement of knowledge, skill, organization, values and capital from the point of generation to the site of adaptation and application. Here, the site of adaptation and application could be within a country or outside the country. Manfield (1975:373) made an important classification of technology transfer which classified technology transfer into vertical and horizontal technology transfer. Vertical transfer refers to the transfer of technology from basic research to applied research to development and then to production respectively, while horizontal transfer of technology implies the movement and use of technology used in one place, organization or context to another place, organization or context (Ramanathan, 2009;5). It is important to note that movement in the "context" of technology involves concerted investment in research and manpower. Souder (1987) describes vertical transfer as internal technology transfer and horizontal transfer as external technology transfer. He further describes vertical transfer as a managerial process of passing technology from one phase of its life cycle to another. According to Ramanathan (2009:5), this elaboration is vital because it serves to reinforce the fact that it may be possible to horizontally transfer technology at any stage of the technology life cycle. The methods of technology transfer vary across sectors and disciplines, therefore it is conceived differently by different scholars. According to Carl (1985:13), the term technology transfer is used in two ways in development literature. First, the transfer of technology between countries; and second, the transfer of technology from the suppliers/inventors to the buyers/users of such technology within a country (for example exchange between organizations in Nigeria or China). The focus of this paper is on the first commonly referred to as international technology transfer. In this regard, Hayami and Ruttan (1971) have identified three stages of technology transfer, i.e. material transfer, design transfer and capacity transfer. Material transfer involves the transfer of products through trade; design transfer is characterized by the transfer of designs of factories and blue prints that can facilitate the production of products by the transferee locally; and capacity transfer involves the transfer of the ability, the know-how (skills and competence), etc are developed in the local personnels to modify and develop new products or improve on existing products 
and the production processes. As Carl (1985:13) observes, in this stage (that is capacity transfer) research and development $(\mathrm{R} \& \mathrm{D})$ are central to the transfer processes. Indeed, this is the stage or point technology would be said to have been transferred or acquired.

Most models of technology transfer in literature seem to suggest that technology transfer or diffusion is only possible through a negotiated agreement between the owners or suppliers of technology and receivers or buyers of technology. For instance, the Bar Zakay model believes that for technology transfer to be possible there must be an agreement between the donor/transferor and recipient/transferee anchored on a project management approach (Ramanathan, 2009:8). According to Ramanathan (2009:8), in this model the activities to be carried out are specified in details and the importance of both the donor and recipient acquiring the skills to undertake technological forecasting, long-range planning and gathering of projectrelated intelligence is emphasized. Similarly, the Behrman and Wallender Model proposed a seven stage process for international technology transfer that may be of great relevance to multinational corporations. These stages among others include: manufacturing proposal and planning to arrive at decisions regarding location and preparing a business case including good resource assessments; deciding the product design technologies to be transferred; specifying details of the plant to be designed to produce the product and other aspects related to construction and infrastructure development; adapting the process and product if needed and strengthening production systems to suit local conditions; and providing external support to strengthen the relationship between the transferor and transferee. As Ramanathan (2009:9) has observed, the major weakness of this model is that, during the first three stages the transferor develops the technology transfer project with little involvement of the transferee thereby reinforcing dependency. How then will it be possible for the recipient or transferee to understand or grasp the technicalities involved in the technology? Furthermore, Keller and Chinta (1990:36), assert that effective technology transfer hinges to a large extent on how the transferor and transferee manage the obstacles that hinder transfer and strengthen ways that would facilitate the transfer. The facilitating initiative or ways refer to the willingness of the partners to device strategies to achieve a "win-win" outcome (Ramanathan, 2009:12). The obstacles could be legal, political, social, economic, cultural and technological. In addition, the UNIDO (1996) model seems to buy the Bar Zakay's project management approach, when it argues that, in the manufacturing sector, once the need for a technology transfer project is established, the steps of search, evaluation, negotiation, contract execution, and technology adaptation and absorption should be sequentially done to ensure effectiveness.

All the above models and many others not mentioned in this work appear to suggest that technology transfer is only possible through a negotiated agreement between the transferor and the transferee. But this is not always true and not always the case in developing nations acquiring technology from the developed nations. It is my argument that most of the Asian countries that have experienced rapid growth and industrial development "stole" their technologies. The question is: if technology transfer is only possible through negotiated agreements, how did nuclear technology get to the Chinese, Indians, Pakistanis, North Koreans and Iranians in the face of the Non-Proliferation Treaty and strong opposition from the West? The simple answer is that they "stole" it. It was never transferred willingly or voluntarily or on a negotiated agreement from the western powers to these Asian nations. Obviously, while it is true that the western nations are willingly to share agricultural technology and other obsolete technologies, they are very unwilling to share medical, manufacturing, space, information technology and other high-technologies with the third world. For the developing nations to acquire advanced technologies they have to "steal" or capture them in some cases. The method/approach of doing this would be explained later in the work.

\section{Technology Transfer and Socio-Economic Development}

Improving the living conditions and productivity levels of the citizens in a country is very significant to its development. Studies have shown that technology transfer is an important means through which substantial social and economic development could be achieved in the developing nations. The benefits of technology 
transfer include industrialization, job creation, increase in income, improved productivity, poverty reduction, etc. For instance, the acquisition of foreign technologies by the East Asian newly industrialized nations; coupled with domestic "technological learning" (that is, efforts and ability to accumulate the capability to change technologies) have been the major factors in their rapid socio-economic development. It is important to note that the wave of industrialization experienced in the Latin American and East Asian countries was to a very large extent due to technology transfer. This led to rapid growth of the manufacturing sector which created jobs in these countries. In China, for example, following the partial liberalization of the economy in 1978, the labour-intensive industries gave way to capital and technology-intensive production. Consequently, as Fu and Gao (2007:26) observed, gross industrial output (GIO) of China increased tremendously with total gross industrial output increasing from 54947 million Yuan in 1995 to 85674 million Yuan in 2000 and 251 620 million Yuan in 2005. Also, Sachs (2005:15) noted that with technology diffusion India experienced information technology revolution, which created jobs for dozens of young women who are specialists in medical data transcription. According to him, these women earn about \$250 to \$500 US dollar a month, depending on their experience. He added that, their income is more than twice the earnings of a low-skilled industrial sector worker in India and perhaps eight times the incomes of an agricultural labourer.

With regard to increase levels of production technology transfer has been very effective in many countries across the world. For example, with the introduction high yield varieties of crops under the Green Revolution agricultural programme many economies adopted and adapted foreign technologies to enhance their productivity. According to Sachs (2005:259-260), sacred of the possibility of widespread hunger because of the rapid increase in global population, the Rockerfeller Foundation took the initiative in developing and promoting high-yield varieties (HYVs) of staple crops in Mexico, Asia and different parts of the world. The HYVs of wheat developed by the Foundation's Institute were used in Mexico immediately after World War II. Mexico went from a large net importer of grain to a major net exporter between 1944 and 1960. Similarly, India went from producing eleven million metric tons of wheat in 1960 to twenty-four million tons in 1970, thirty-six million tons in 1980 and fifty-five million tons in 1990 (Sachs, 2005). Other crops for which HYVs had been developed in like manner are rice and potato, to mention a few. Furthermore, in the area of improving health care drugs, vaccines, etc produced in one part of the world are used in other parts to treat and control diseases, especially in the developing nations.

Indeed, technology transfer has been the basis for the East Asian countries leap into global prominence in the production of toys, cars, footwears, garments, spear parts, electronics, etc. Nonetheless, studies have shown that the ability of developing countries to use technology transfer to develop their domestic capacities (allowing such countries to reap the social and economic benefits of existing technologies) have been mixed (WACC, 2000). Obviously, there are wide variations between countries and between sectors within individual countries. As WACC (2000) has observed, "the disparities between-andwithin developing countries in benefiting from technology transfer and the accumulation of domestic technological capability is far from straightforward". Simply put, more technology transfer agreements do not necessarily automatically translate to more technological and economic development. This is so because some nations understood the politics and dynamics of technology transfer better than others. Put differently, while some developing nations concentrate on the process of technology transfer agreements to acquire foreign technologies (which in most cases the owners are not sincerely willing to transfer), others simply capture/spy/steal the technologies they need and replicate, innovate and modify them through intensive and extensive investments in research locally. This, essentially, accounts for the differences noticed in the level of technological and economic development among developing nations.

\section{Technology Transfer: The Asian Experience}

Most of the Asian countries vigorously pursued the acquisition of foreign technologies to grow their economies immediately after World War II and in the 1960 and 1970 periods. The methods adopted were 
multi-dimensional and recorded various degrees of success. Essentially, the "spy, copy or steal and replicate approach" (not discussed in development literature) was the most effective. For instance, in the early 1950s, Japan had a disadvantage in producing capital-intensive goods. According to Aggarwal (2010:32) the Japanese government adopted a policy of fostering particular industries for rebuilding and modernizing the industrial sector. Sule-Kano (2000) asserts that the policy which the Japanese government adopted was one in which many Japanese were sent to the United States of America and Europe to study in their institutions and work in their factories so as to acquire the necessary knowledge and skills. To Sule-Kano the method of learning by the Japanese was the "Cram method", which essentially involves cramming or copying in details the technologies, so as to replicate them upon return to Japan. The method paid-off as Japan became industrialized using foreign technologies brought in by the Japanese returnees. While it is true that foreign direct investments (FDIs), direct investments by multinational corporations (MNCs), licensing arrangements and original equipment manufacturing (OEM) channels/methods of technology transfer were also employed in transferring foreign technologies to Japan the capture/cram and replicate method was the most successful. This was why the Japanese rapidly came into prominence in the manufacturing sector, especially automobiles and electronics. It is important to note that if these manufacturing concerns were produced through licenses, arrangements, MNCs, FDIs and OEM, the products would carry the brand name of the parent companies. Products like Toyota, Nissan, Honda, Sony, Toshiba, etc bearing Japanese brand names show their independence and Japan's ownership of the technologies. There is no doubt that automobile technologies used in these products were gotten from Europe and USA.

The Chinese experience with technology transfer was not very different with that of the Japanese. Though the FDIs, MNCs, Licensing arrangements and OEM channels were used, it was the Chinese returnees who actually brought foreign technologies to China. As Sachs (2005:163) asserts, China had the benefit of overseas Chinese communities which acted as foreign investors and role models. Fu and Gao (2007:27) disclosed that in China technology transfer or spillover through FDIs and other conventional methods to indigenous firms are limited. A study carried out by Nolan in 2002 shows that after more than a decade as a joint venture partner to Volkswagen, Shanghai Auto had no capacity at all to compete as an independent carmaker. Similarly, Hu and Jefferson (2002) observe that in the Chinese electronics industry there was significant productivity depression rather than positive spillover effects of FDIs on domestic firms. China's technological advancement and innovation were enhanced due to deliberate government policy in the establishment of high-tech industrial development zones (HIDZs) which engage in intensive research and development (Fu and Gao, 2007:27-28). Indeed, Chinese professionals working in the USA and Europe have been variously accused of spying or involved espionage activities trying to "steal" different technologies in the USA and Europe. Recently, it was reported that Chinese hackers stole business secret (technology) from a "high-tech" firm in Taiwan (Nigerian Info News, 2013). Usually, these Chinese returnees come back with skills and knowledge which they replicate and innovate through intensive research.

The Indian experience is not different from the above two countries examined. Essentially, Indians, who studied and work in Europe and America returned home and replicated their skills and technical expertise domestically thereby transferring technologies to local industries. Discussing the Indian situation, Sachs (2005:179) asserts that Indians who graduated from the Indian Institute of Technology (IIT) migrated in large numbers to the USA, worked in world-class information technology (I.T) firms and after many years returned and established IT firms in India. According to him, by the late 1990s India's centres of IT operations, in the cities of Bangalore, Chennai, Hyderabad and Mumbai, were the new destinations for major companies looking for software engineering, data transcription services, computer graphics, back-office processing, computer-aided design and a myriad of other IT-based activities. Obviously, India plays a prominent role in the global IT industry. India has also made waves in the health sector, benefiting substantially from "medical tourism". Indian pharmaceutical companies have developed drugs and vaccines through technologies acquired from foreign firms. Recently, through intensive research, an Indian Pharmacy produced a modified version of a Swiss drug giant, Novartis cancer drug, Glivec, for which Indian Supreme Court rejects the 
petition of Novartis a parent request in the production of the drug in India (the generic version of the cancer drug produced by the Indian pharmacy is known as Imatinib Mesylate 100 and 400mg).

Obviously, these Asian countries have made significant technological advancement through concerted efforts at research and development and investment in manpower development. It is important to note that replicating, innovating, and modifying foreign technologies in these Asian countries was possible because governments in these countries invested heavily infrastructure, human capital and research and development, and put in place relevant policies to achieve specific set goals in this regard. Indeed, the absorptive capacity of the personnels in the recipient country is critical to the process of receiving and localizing foreign technology. According to Tran (2003:261) the absorptive capacity in Asia has increased considerably. It is not therefore, surprising that the three Asian countries studied made significant advances in their drive toward the acquisition of foreign technologies. To Tran, the capacity for technology absorption is a synthesis of the educational and skill levels of the labour force, the availability of local entrepreneurship, and the government's ability to maintain a stable political and macroeconomic environment. In this regard upgrading the educational system is emphasized in any country that wishes to acquire foreign technology.

\section{Nigeria and the Dilemma of Technology Transfer}

Over the years, since the country's independence in 1960, Nigeria has made frantic efforts to achieve technological advancement. These efforts were most visible in the adoption of the import substitution industrialization (ISI) strategy and the Green Revolution agricultural programme. The ISI was aimed at fostering a national economy fairly independent of the rest of the world (Aderemi, 2002:8). It was characterized with the establishment of production/assembly plants in the country; to assemble or manufacture product in the country for the domestic market initially and later for export. This was aimed at conserving foreign exchange, diversifying the econmy, create employment and acquire the technology in the process. Consequently, Peugeot, Volkswagen, etc established their assembling plants in Nigeria. However, as Ake (1984:146) noted, the ISI strategy failed largely because of policy disarticulation. On the other hand, the Green Revolution Programme was an initiative of the Rockefeller Foundation geared towards developing and promoting high-yield varieties (HYVs) of staple crops so as to ensure global food security (Sachs, 2005:259). Nigeria was among the developing countries that implemented the Green Revolution Programme in the 1980s. While Green Revolution succeeded in India, Mexico and other third world countries it failed woefully in Nigeria.

Considering the importance of technology to growth and development, Emeagwali (2010) argues that for Nigeria to achieve development the one hundred million young Nigerians whose weapon is knowledge must develop their intellectual capital in order to build a stronger Nigeria using technology. At present, efforts at the acquisition of foreign technologies seem not to be working. This is because, the approach the Nigerian government has adopted in its attempt to achieve technology transfer seems to suggest that technologies can only be transferred through patent and licensing agreements with multinational corporations and through foreign direct investments. All the governments' efforts at technology transfer since the 1960s tow these lines. The end product of these processes is MNCs establishing their organizations in the country, produce their products/commodities for the consumption of the Nigerian people without Nigerians acquiring the technical and managerial skills and know-how. While it is true that the people benefit from these activities, technology cannot be said to have been transferred. In other words, technology cannot be said to have been transferred if the owners of the technology are those utilizing it in a foreign country, as has been the case in Nigeria. Technology can only be said to have been transferred when the local people (in this case Nigerians) acquire, adopt, absorb and utilize it on their own. As Ake (1984:106) has argued, technological capability is defined in terms of the technological innovation as reflected in patents granted. Simply put, for Nigerians to be said to have acquired a particular technology, they must have made an innovation in the production of a commodity/product and have the patent for that product. For example, in Thailand, the makers of "Est" after 
partnering with American beverage giants Coca-Cola and Pepsi for some time, the Thai partners adopted and modified the technology to produce their local alternative called "Est" for which they have the patent. At present, Est control 19 percent of the Soda market in Thailand, with Coca-Cola and Pepsi having 50 percent and 31 percent respectively (Aljazeera News, 2013).

Indeed, the acquisition of foreign technologies and development of indigenous technologies have been a great challenge to Nigeria. It is not therefore surprising that after over half a century of oil exploration and production, Nigeria still depends on foreign expertise for oil drilling activities in the country. Similarly, despite the fact that Nigeria is a huge market for cell phone, with 115 million people using GSM in the country, none of the cell phones is produced in the country. The National Office for Technology Acquisition and Promotion (NOTAP) asserts that Nigeria has spent over N300 billion on technology transfer agreements in a 10 years period (Business News, 2011). Yet, in our hospitals most medicines are imported, the equipment are imported; in the banking sector most of electronic gadgets, software, etc are imported and almost 100 percent of machinery used in our industries are imported. Nigerians have not been able to significantly acquire foreign technologies using the technology transfer agreement model, yet the government is still bent on adopting that approach. For example, after the disappearance of Nigeria's Communication Satellite (NIGCOMSAT1), the Nigerian government replaced it with NIGCOMSAT1R. The government then entered into an agreement with the builders of the new satellite to train Nigerian engineers so that they too can become satellite builders in future (Osuagwu, 2011:12). The Executive Commissioner for Engineering and Standards, Nigeria Communication Commission, Bashir Gwandu, asserts that the government was in search of satellite companies to build a second satellite, but would only be interested in companies that would transfer technology to Nigerian engineers (Osuagwu, 2011:12). What has become clear from the above is that over all these years, the Nigerian government has not understood that owners of technologies do not willingly transfer technology, rather those interested in acquiring technologies "steal" them, as was the case with most Asian economies. A Business News reporter puts it this way:

If you open your gate as a country for people to bring their technology, money and know-how to come and make money in your country and depart, you are not doing well. What you should do is to use a "magnate" to capture their technology and managerial know-how and be made better. The graduates from our institutions are those magnates, but if the magnates are bad what can we do? So the education system has to push it. By now it should be Nigerians exploring our oil, designing our refineries. By now we should not allow one drop of crude to leave; let us refine them in this country. That is where the jobs are but we are not taking this opportunity... (Business News, 2011).

\section{The Role of Research in Technology Transfer}

One of the indices of developing or underdeveloped economy is technological backwardness or low technological advancement. Technologies are not acquired by accident, rather they are acquired through concerted efforts at research by tertiary institutions and research institutes. Discovery of new technologies, improving on existing ones and perfecting acquired technologies require concerted efforts and commitment in research at tertiary institutions, research institutes and production factories. According to Nelsen (2003:301) universities and other institutions are the main sources of researches that lead to the development of technologies and lead compounds that are developed into new products (for example, drugs and vaccines). To Nelsen, the primary ways in which universities disseminate their discoveries are through publications and the training of students. A study carried out by Bozeman (2006:634) involving over 1200 universities, industries and government laboratories, disclosed that 23 percent of university laboratories view technology development as a major mission, compared to 51 percent of government laboratories. Furthermore, Bozeman's study reveals that whereas 70 percent of university laboratories see basic research as a major mission, 42 percent of government laboratories do. With regards to technology transfer to industrial organizations the study indicated that 40 percent of university laboratories were involved in technology 
transfer and 51 percent of government laboratories do.

For technologies to be commercialized the universities, research institutes and industrial organizations must work in synergy. Technological knowledge itself is disseminated by universities via publication but the commercial use of some of that knowledge is restricted by patents to companies to whom the universities grant licenses (Nelsen, 2003;302). It is such patent that encourages companies to fund research and development $(R \& D)$ in tertiary institutions. Funding is very important for R\&D activities to be sustainable and successful. In developed economies governments and private companies substantially fund research despite the risk involved in it. For example, though the US government in principle does not support "cloning of babies", the Clinton administration gave a research institute $\$ 50$ million dollar for stem-cells research just to acquire the technology and knowledge (Harry and Ikiriko, 2013:116). On the other hand, in most developing economies private companies' collaboration with tertiary institutions in funding research is almost absent, only the government does. Nelsen (2003:302) observes that university research is usually at so fundamental a level (embryonic level) that investment in development involves substantial risk, because at this point neither the technical practicability nor the market acceptability of the invention is proven. According to Nelsen, more inventions will fail than will reach the market, particularly in the medical field; therefore companies will be willing to take on the risk of funding at the embryonic stage if they will be protected from potential competitors through the exclusive use of the patent. Thus most universities believe that the primary purpose of their technology transfer activities is to induce investment in university technology by private businesses to bring products based on the technology to the public (Nelsen, 2003:302). Bozeman (2000:635) asserts that the share of university R\&D supported by industry has increased. According to him, in 1970, only 2.6 percent of university R\&D was supported by industry, but by 1990 that percentage was up to 6.9. The increase in industry supported university R\&D created new university -industry $R \& D$ centres during the period, 1970 - 1990. Cohen, et al (1993), reveal that as at 1990 there were an estimated 1056 universityindustry R\&D centres in the US.

To achieve rapid technological advancement the Asian economies mentioned above financed research and development in their tertiary institutions and established research zones. In this regard, China for example, established the high-tech industrial development zones (HIDZs). According to Fu and Gao (2007:27), the HIDZs is one of the important policy measure that has been introduced deliberately to enhance technological advancement and innovation in China. They disclosed that after about 15 years of their introduction, HIDZs shared half of China's high-tech product of the gross industrial output and one third of China's high-tech product export in 2005. Fu and Gao (2007:28) further disclosed that, the main advantage of the HIDZs is their intensity of R\&D, and their expenditure on R\&D in 2002 stood at 31.4 billion RMB Yuan and shares 24.4 percent of China's total expenditure on R\&D. In the next four years, HIDZs expenditure on R\&D tripled to 105.4 billion Yuan and the share rose to 35.1 percent in 2006. Indeed, these statistics make the HIDZs very important innovation entities in China, especially in the area of R\&D. It is not surprising therefore to see China make giant strides in manufacturing, space technology, etc, etc. Today, China from a relatively underdeveloped or developing economy status is the second largest economy in the world. China did not attain this height by accident but through concerted efforts at research and innovation in science and technology. Indeed, breakthroughs in technology are transferred across the country and across sectors in the economy. Such is the story of the Asian economies. So what can Nigeria learn from the experiences of these Asian countries.

\section{Lessons from the Asian Economies}

Most of the Asian countries examined above were former colonies that got their independence at about the same time with Nigeria, except perhaps China, which was not a former colony. In the 1960s and 1970s they share the same or similar development characteristics with Nigeria. However, today they are far ahead of Nigeria in the global development ranking. The question is: What have they done differently from Nigeria? 
We will attempt to answer this question later in this section. Emeagwali (2010), in a piece titled "Africa Must Innovate or Perish", asserts that scientific discoveries lead to technological inventions and are the foundations of knowledge: the knowledge that must precede the development of new products, services, industries, jobs, and new wealth. In other words, what Emeagwali is saying is that without breakthrough in research resulting in scientific discoveries and technological advancement there can never be development in the continent at large and Nigeria in particular. Thus, he asserts:

In human history, technological development and economic growth have gone hand-in-hand. A nation that is second to none in science is second to none in economic power. The grand challenge for African scientists is to make discoveries and inventions that can be domesticated and diffused into the continent's economy... It's innovation and technology that create new products, which in turn, create new wealth that alleviates poverty.

Recently, participants at a national workshop on "Packaging Research and Development (R\&D) and Inventions for the Market", organized by the National Office for Technology Acquisition and Promotion (NOTAP) in collaboration with Islamic Education, Scientific and Cultural Organization (ISESCO) have decried the weakness in institutional frameworks for effective technology transfer in Nigeria (NOTAP, 2012). The participants observed that the weakness in capacity to turn scientific outputs to be industrially applicable had led to high consumption of foreign technologies by the general public, industries and other vital sectors of the Nigeria economy. Obviously, Nigeria has not been successful in achieving technology transfer, since Nigerians have not been able to adapt, modify and make innovation on available foreign technologies in the economy. The question is: why has technology transfer eluded Nigeria all these years? The simply answer is faulty assumption of the methods of technology transfer. From all indications, the National Office for Technology Acquisition and Promotion (NOTAP) still assumes/believes in acquiring technologies through technology transfer agreements with owners of such technologies. This has been proven to be faulty assumption and approach. As earlier argued, technology is acquired through research and not by voluntary transfer by owners through transfer agreements. And this is what Nigeria has been doing differently from the Asian economies.

The lessons Nigeria should learn from the Asian economies are broadly classified into two. First, the Asian economies purposely invested in human capital development so as to produce the right mix of manpower covering the different sectors of their economies. For example, South Korea's per capita expenditure on education in 1970 was 9.1 US dollars and attained 71 percent literacy rate, while India spent 1.58 US dollars per capita on education and recorded 30 percent literacy rate, and Malaysia spent 16.4 US dollars per capita and attained 55 percent literacy rate in 1970. By 2000, they all improved their expenditure on education. South Korea increased to371.4 US dollars and achieved 98 percent literacy rate, India increased hers to 13.77 US dollars and recorded 60 percent literacy rate, and Malaysia increased hers to 223.4 US dollars and attained 90 percent literacy rate (World Development Indicators, 2001 and World Development Report, 1982). During the same period, that is in the year 2000, Nigeria's per capita expenditure on education was 0.7 US dollars (The African Debt Report, 2000). Recently, a UNESCO report disclosed that 1 out of 5 Nigerian children is out of school. Indeed, the report indicated that Nigeria top the list of countries with out of school children in the world. This is the first thing the Asians have done differently from Nigeria. They created a solid human capital base that helped in driving their economies to greater height. And this will take us to the second thing they have done differently.

The second is deliberate investment in research and development (R\&D). The human capital/resources of these countries, so well trained, traveled to Europe and America for further studies and also worked in the production factories, learn by doing externalities, crammed the technologies, returned home and replicated the knowledge/technologies they have acquired through research. The Asian governments established specific institutions for these activities through which foreign technologies were adapted, modified and innovations made to secure patents. Good examples are the India Institute of Technology (IIT) where 
rigorous IT based activities were carried out and the Chinese HIDZs where high-tech research activities are carried out. All these contribute to the technological advancement of the Asian countries mentioned in this study. Today, China is a very strong technological giant in the world. The Chinese recently launched their space craft by sending 15 Chinese astronauts to space from Chinese soil.

Nigeria should learn and adopt the Asians approach to the acquisition of foreign technology if Nigeria must become one of the 20 largest economies as envisaged by our leaders. There is no gainsaying the fact that the method of technology transfer adopted by the policymakers in Nigeria has not worked, so a new method, in this case the methods of the Asians, must be adopt sincerely and honestly so as to achieve good result. In addition, Nigeria must fund education properly to create the required human capital base, as was the case in the Asian countries. Poor funding of education (and to a large extent health care, the other element in human capital development) has been a very serious factor in the nation's development pursuit. It is adequate funding of education that would create those Emeagwali (2010) describes as "foot soldiers", whose weapon is knowledge that would capture the needed technologies to industrialize the Nigerian economy. This the government must do if we must acquire foreign technologies, develop indigenous technologies and become industrialized nation to create jobs for our teeming youth population.

\section{Conclusion}

Over the years, Nigeria has made frantic efforts to acquire foreign technologies so as to bring development to its citizenry. Yet the country is still very backward technologically. Some of the Asian economies which were at par with Nigeria in the 1970s are now far ahead of Nigeria technologically and had attained significant socio-economic development. The paper argued that the reason for the difference in the level of technology and socio-economic development between Nigeria and the Asian economies such as South Korea, India, China, Malaysia, etc, is the method they adopted in their technology transfer efforts. While Nigeria depends on the traditional method of negotiated agreements with owners of technologies to effect transfer, the Asian countries adopt a non-conventional method of cram, copy or "steal" and replicate through intensive and extensive research and innovation, hence, the rapid technological advancement of these nations. Essentially, they invest heavily in research and development in their universities and other tertiary institutions and specifically established research institutes in their nations. Therefore, the conclusion of this paper is that, Nigeria must toe the line of the Asian economies mentioned in the study, if it really wants to acquire foreign technologies. This is because the traditional methods adopted over the years have failed and will continue to fail. Indeed, for Nigeria to acquire foreign technology the government must establish specifically targeted high-tech institutions; invest heavily in research and development, and substantially fund universities and other tertiary institutions in the country. This is what the Asian economies have done differently from Nigeria, and that is what is responsible for their rapid technological advancement and development.

\section{References}

Aderemi, A. (2002), Towards An Interpretation of Africa's Development Process: NEPAD and New Global Orthodoxy, A Paper presented at the International Conference on the Challenges of NEPAD, Yaoundé, Cameroon, October 24 25.

Aggarwal, A. (2010), Economic Impact of SEZs: Theoretical Approaches and Analysis of Newly Notified SEZs in India, Munich Personal RePEC Archive (MPRA) paper No. 20902.

Ake, C. (1984), A Political Economy of Africa, New York: Longman Inc.

Aljazeera News (2013) Report on Thailand's Markers of Est, Wednesday $17^{\text {th }}$ April, 2013.

Aljazeera News (2013), Report on Indian Supreme Court Ruling on Patent for Novartis, Monday $1^{\text {st }}$ April, 2013.

Bozeman, B. (2000), Technology Transfer and Public Policy: A Review of Research and Theory, Research Policy 29, Elsevier Science.

Business News (2011), Nigeria Spent N300bn on Technology Transfer Agreements in 10 years, www.business.com.ng. 
Carl, E.P. (1985), Private Sector Research and Technology Transfer in Asian Agriculture: Report on Phase I Aid Grant OTR-0091-G-ss-4195-00, Economic Development Centre, Bulletin Number 85 - 5.

Cohen, W. et al (1993), University - Industry Research Centres in the US; Report to the Ford Foundation.

Emeagwali, P. (2010), Africa Must Innovate or Perish, Nigeria News and World Affairs, on Nigerians Abroad Live.com.

Fu, X. and Gao, Y. (2007), Export Processing Zones in China: A Survey, A Report Submitted to International Labour Office.

Harry, D.M. and Ikiriko, S. (2013), Human Capital Development and the Transformation Agenda in Nigeria, in Journal of Management and Environmental Studies, Vol. 1, No. 1.

Hayami, Y. and Ruttan, V.W. (1971), Economic Development: An International Perspective, Baltimore: The John Hopkins University Press.

Hu, A. and Jefferson, G. (2002), FDI Impact and Spillover: Evidence from China's Electronic and Textile Industries, World Economy Vol. 38, No.4.

Keller, R.T. and Chinta, R.R. (1990), International Technology Transfer Strategies for Success, The Executive Vol. 4 No. 2.

Mansfield, E. (1975), East-West Technology Transfer Issues and Problems, International Technology Transfer Forms, Resource Requirements and Policies, American Economic Review, Vol. 65, No. 2.

Mittleman, J.H. and Pasha, M.K. (1997) Out from Underdevelopment Revisited: Changing Global Structures and the Remarking of the Third World, New York: St Martin's Press.

Nelsen, L. (2003), The Role of University Technology Transfer Operations in Assuring Access to Medicines and Vaccines in Developing Countries, in Yale Journal of Health Policy, Law and Ethics, Vol. 3, No. 2.

Nigerian Info News (FM 92.3) (2013), Report on Chinese Hackers Steal Business Secrets from Taiwan, Thursday, March $21^{\text {st }}, 2013$.

Nolan, P. (2002), "China and the Global Business Revolution," Cambridge Journal of Economics, Vol. 26.

NOTAP (2012), Workshop Participants Decry Passive Technology Transfer in Nigeria, www.notap.gov.ng/content Iworkshop-participants-decry-passive-technology-transfer-nigeria.

Osuagwu, P. (2011), Builders of Nigeria's Second Satellite Must Transfer Technology - Gwandu, Vanguard Newspaper May $31^{\text {st }} 2011$.

Ramanathan, K. (2009), An Overview of Technology Transfer and Technology Transfer Models, A Paper prepared for the Asian and Pacific Centre for Transfer of Technology (APCTT), on www.technology4sme.net.

Sachs, J.D. (2005), The End of Poverty: How We Can Make It Happen in Our Lifetime, England: Penguin Book Ltd.

Souder, W.E. (1987), Managing New Product Innovation, New York: D.C. Health.

Sule-Kano, A. (2000), Lecture Note on Public Policy Analysis, Department of Political Science, Usmanu Danfodiyo University, Sokoto (Unpublished).

Tran, V.T. (2003), Technology Transfer in the Asian Pacific Region: Implications of Trends Since the Mid-1980s, Japan Centre for Economic Research (JCER) Tokyo.

UNIDO (1996), Manual on Technology Transfer Negotiations, UNIDO (ID/SER0/18) Vienna.

World Association Christian Communication (2000), What is Technology Transfer, Toronto: WACC 4x7.

World Development Indicators (2001), Vol. 1, No. 1 April 2001, Washington D.C. A World Bank Publication.

World Development Report (1982), Oxford University Press, A World Bank Publication. 
